\title{
Morphology and syntax in the Scandinavian vernaculars of Ovansiljan ${ }^{1}$
}

\section{Introduction}

Within linguistics, there is a long tradition of connection morphology with syntax, in a more or less direct way. Attempts to correlate morphological and syntactic phenomena in languages with each other have been known in linguistics since at least the $14^{\text {th }}$ century (Håkansson 2008:34 and works cited therein). In more recent times, these proposals have often been formalized within the generative framework.

Since the 1980s, much of the diachronic and synchronic variation within the syntax of Nordic languages has been explained by a assuming a number of parameters. This explanation has its roots in a parametric approach to syntax, as developed in the Principles \& Parameters theory (Chomsky 1981). This approach presupposes that Universal Grammar contains principles determining the frames of language. Some of the principles are parametric - that is, they can have more than one value, and the differences between languages are seen as an effect of different values of such parameters. Further, it has been assumed that each parameter must be related to a morphological factor (Borer 1984; Chomsky 1981). The parametric approach has been under criticism, and more recent theories of generative syntax have been developed. Nevertheless, several works assuming a connection between morphology and syntax have been published. This paper will focus on work connecting verbal morphology with a clustering of syntactic phenomena in the Scandinavian languages. Both Bobaljik and Thráinsson (1998) and Holmberg (2010a) maintain the hypothesis that morphological evidence - in the form of 'rich' verbal agreement - signifies a positive setting of a parameter

\footnotetext{
${ }^{1}$ I would like to thank here my Ovansiljan informants for making this research possible. Further, I thank HansOlav Enger, David Håkansson, Kari Kinn, Yvonne van Baal and the two anonymous reviewers for their certainly valuable comments. Yvonne van Baal also helped me considerably with the revision of the text and came with many great insights. I remain solely responsible for all errors of fact and interpretation. This research has been financed by the Nordic Centre of Excellence in Microcomparative Syntax (NORMS), http://norms.uit.no/.
} 
that in turn makes certain syntactic patterns possible. Although they differ in the description of rich verbal morphology and in the exact syntactic phenomena related to the parameter, the relation between morphology and syntax is evident in both studies.

The present paper intends to show how this relation works when tested on a group of Ovansiljan vernaculars, East Scandinavian non-standard varieties that are closely related to each other and less closely related to Swedish, Norwegian and the other Nordic languages. I will mainly focus on the assumed relation between morphology and syntax, rather than on the question on the suitability of the parametric approach to capture the data. The unidirectional generalization is that the syntactic patterns in question are not expected to appear when the morphological evidence is absent, whereas they may appear when the morphological evidence is present. The Ovansiljan vernaculars form an ideal testing ground for this hypothesis: five of the discussed vernaculars have retained verbal agreement in number and person, whereas two others have not. That makes it particularly interesting to test the typological predictions proposed in the above-mentioned works on these until recently less-studied non-standard vernaculars.

After having presented the vernaculars of Ovansiljan in Section 2 and the data collection methodology in Section 3, two of the approaches assuming a relation between morphology and syntax are discussed in light of the new data. In Section 4, the older parametric approach put forth by Bobaljik and Thráinsson (1998) is discussed. Then, the more recent approach by Holmberg (2010a) is considered in Section 5. In both sections, it will be clear that the hypotheses encounter difficulties when faced with the Ovansiljan data. Section 6 concludes with a summary. 


\section{The vernaculars of Ovansiljan}

The vernaculars that are discussed in this paper are all spoken in the region of Ovansiljan, located in the northern part of the Dalecarlia province (swe. Dalarna) in western Sweden. According to Levander (1925:1), there are seven vernaculars of Ovansiljan, here in alphabetical order: (1) the vernacular of Älvdalen, termed here as Övdalian²; (2) the vernacular of Mora; (3) the vernacular of Ore; (4) the vernacular of Orsa; (5) the vernacular of Sollerön; (6) the vernacular of Våmhus and (7) the vernacular of Venjan. The geographical spread of the vernaculars is shown in Map 1.

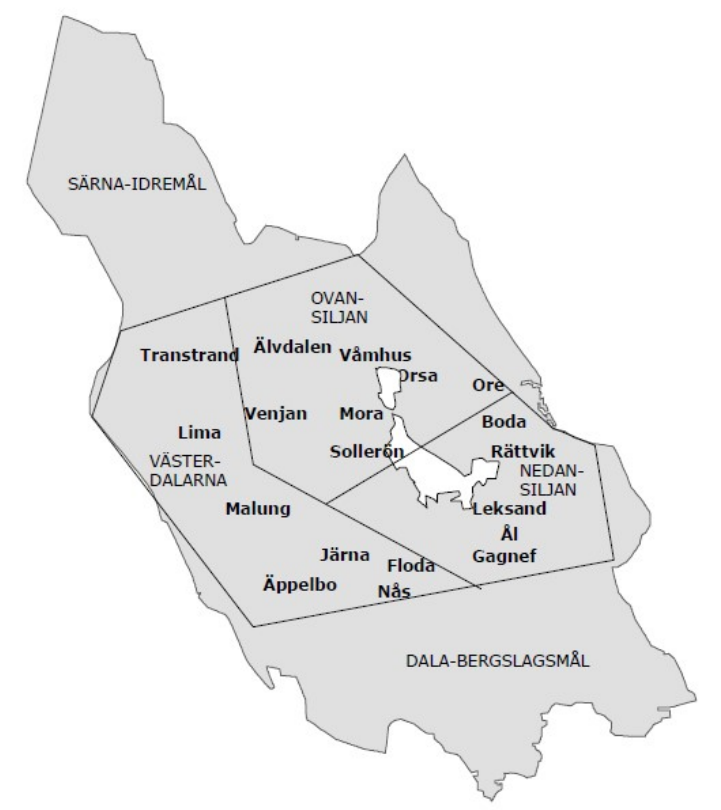

Map 1: The geographical spread of the Ovansiljan vernaculars in the province of Dalecarlia (from Dahl 2005:1)

In Swedish dialectology, the vernaculars discussed here are often known as Ovansiljanmålen, or "Upper Siljan vernaculars” (Dahl 2005:1). They are descendants of a variety of Old East Scandinavian, labelled Old Dalecarian (Swe. forndalska) by Levander (1925). The most genuine Dalecarlian dialects are today limited to the north-western parts of the province (Garbacz 2010:29-31). With the exception of

\footnotetext{
${ }^{2}$ In the international literature, Övdalian is sometimes also labelled Elfdalian (Sapir 2005; Dahl \& KoptjevskajaTamm 2010), Oevdalian (Holmberg 2010a, b) and Älvdalsmålet (Thráinsson 2010).
} 
Övdalian, spoken by not more than 2,400 people (Larsson et al. 2008), it is unknown how many people speak the vernaculars mentioned above. Most likely, the number fluctuates between a few hundred to not more than one thousand speakers for each vernacular. The speakers are mostly, but not exclusively, elderly people, and the vernaculars are most often their first language, as many of them first learned Swedish when they started school.

The common view among Scandinavian dialectologists is that the Ovansiljan vernaculars hold a unique position among the Scandinavian varieties (Hallberg 2005:1697). They exhibit a number of differences compared to the other Scandinavian languages, as well as to the neighbouring dialects, at every level: phonetic, phonologic, morphologic, syntactic and lexical - see especially Levander $(1925,1928)$ for further information. The phonology and morphology of all of the Ovansiljan vernaculars are given detailed descriptions by Levander $(1925,1928)$.

With the exception of Övdalian, traditionally considered the most conservative of the Ovansiljan vernaculars, the other vernaculars are poorly described. ${ }^{3}$ The vernacular of Orsa has been treated in a small number of works, which embrace an early, general paper that is no longer up-to-date (Boëthius 1918) and a recent dictionary containing around 5,000 words (Ohlsén \& Olander 2010). As for the other vernaculars, there exists a small dictionary (containing less than 2,000 words) of the Våmhus vernacular (Ask 2000) as well as dictionaries for the vernaculars of Sollerön (containing around 4,000 words in addition to some grammatical information; Andersson \& Danielsson 1999), the vernacular of Venjan (containing about 2,000 words; Wennberg 2007) and the vernacular of Ore (an online dictionary containing around 2,300 words; http://oremal.orerattvik.se). Further, one will find a brief description of the vernacular of Sollerön (Måsan 2002), a short article that deals with the

\footnotetext{
${ }^{3}$ The bibliography of linguistic literature on Övdalian is given in Garbacz (2010:23-53). Övdalian is spoken in about 20 villages located on both sides of the Österdalälven-valley, see Garbacz (2010:23 ff.), and its form differs between the villages, at least as far as phonology and morphology are concerned (Steensland 2000:361).
} 
development of three diphthongs in the same vernacular (Björklund 1994) and two old, short descriptions of the vernacular of Ore (Boëthius 1907 and Tannerhagen 1913).

\section{Data collection}

The data for this article were collected from a few native speakers of each Ovansiljanvernacular, aged 48-82 (born between 1929 and 1963), from between one and five individuals for each vernacular. ${ }^{4}$ The grammaticality judgements presented in the article are based on unison judgements, unless stated differently. Although the number of informants may seem very low and therefore not representative, it must be kept in mind that collecting data from just one person to serve as the data foundation of a scientific work (this person often being a linguist, who is an author of the same paper) is seldom questioned, at least in generative linguistics. The consultants have been carefully examined by the author in long, in-depth interviews, followed by questionnaires that were sent to the consultants by mail and returned to the author when completed. The native language of all the investigated persons was the vernacular in question, as they first learned Swedish in school. All interviews were carried out by the author during a visit to the Ovansiljan region in May 2010 and June 2011.

The consultants came from the villages of Åsen, Brunnsberg, Loka and Klitten (Övdalian); Våmhus (the vernacular of Våmhus); Färnes (the vernacular of Mora); Orsa (the vernacular of Orsa), Sollerön (the vernacular of Sollerön); the northern part of the village of Venjan (the vernacular of Venjan) and Ore (the vernacular of Ore). The data were collected by means of elicitation of grammaticality judgements, which means that the consultants were asked whether they would consider the sentences presented to them as grammatical or not. The most

\footnotetext{
${ }^{4}$ Ore: one informant born 1963; Orsa: two informants born 1945 and 1963; Mora: three informants born 1929 , 1940, and 1948; Sollerön: two informants born 1958 and 1935; Venjan: two informants born 1939 and 1960; Våmhus: one informant born 1942 Älvdalen: four informants born 1937, 1928, 1930, and 1939.
} 
important reasons for the choice of this method are (apart of the lack of any text corpus of the Ovansiljan-vernaculars ${ }^{5}$ ) (1) the need for negative evidence (that is, information on which patterns are not grammatical in a particular language) and (2) the possibility to examine sentences that occur very rarely in corpora or in speech. ${ }^{6}$

\title{
4 Bobaljik and Thráinsson (1998): The Split-IP Parameter
}

Bobaljik and Thráinsson (1998:37) state the following:

\begin{abstract}
We predict a correlation with other morpho-syntactic phenomena reflecting the presence/absence of AgrPs: "extra" subject and object positions, transitive expletive constructions, multiple infelectional affixes, etc.
\end{abstract}

Following an earlier paper by Thráinsson (1996:262), the authors thus propose that the IP in a particular language can be either split or unsplit and that this fact is subject to parametric variation. The so-called Split-IP Parameter (hereafter SIP) is set by morphological evidence that is, "the possibility of multiple inflectional morphemes on the verb stem, specifically the co-occurrence of discrete tense and agreement morphemes" (Bobaljik \& Thráinsson 1998:67). This is the case in Icelandic. In cases where morphology is insufficient, as in Faroese and Yiddish, the syntactic phenomena related to the SIP can still be found, as the authors propose the following:

Note that with respect to acquisition, the view we advocate here implies that the child must be attentive to converging evidence from a number of different sources to determine the setting of a parameter such as the SIP. While the inflectional

\footnotetext{
${ }^{5}$ An exception being one small corpus of Övdalian (http://www.tekstlab.uio.no/nota/scandiasyn/).

${ }^{6}$ See Sandøy's (1994) arguments in favour of using grammaticality judgements in research on Scandinavian dialect syntax and a short discussion on the same subject in Garbacz (2010:59).
} 
morphology of Icelandic unambiguously sets the parameter to a split IP, the inflectional morphology of Faroese or Yiddish is not sufficient to set the SIP, and the child must listen for other evidence such as verb raising or transitive expletive constructions to set the parameter correctly.

Bobaljik \& Thráinsson (1998:61)

This means that the relation between morphology and syntax that Bobaljik \& Thráinsson (1998) propose is unidirectional: languages with enough morphological evidence will set the SIP and hence show syntactic consequences, whereas languages with insufficient morphological evidence can either show or lack the SIP setting. The morphological evidence for a positive value of the SIP is a clearly separable tense and agreement morphology (Bobaljik \& Thráinsson 1998:58). Such morphology is, according to Thráinsson (2007:59), found both in Icelandic, Old Swedish and Övdalian, but not in, for example, the standard Mainland Scandinavian languages. The differences between the Danish, the Icelandic and the Övdalian paradigm are shown in Table 1 - adapted from Thráinsson (2007:59). Since the Övdalian verbal forms given by Thráinsson are incorrect, I list only the correct forms. ${ }^{7}$ His erroneous Övdalian forms (Thráinsson 2007:59) do not, however, influence the line of argument.

\footnotetext{
7 Thráinsson (2007:59) has taken the Övdalian forms from Vikner (1995b), who writes that the Övdalian paradigms are "based on Levander (1909:62-63, 80, 84-88)" (Vikner 1995b:7). In consulting the relevant pages in Levander (1909), one discovers that the inflection pattern of the Övdalian verb ära ('to hear') is not mentioned there. Vikner (1995b) has assumed how the forms would be, without having sufficient knowledge of Övdalian and/or consulting somebody who does have such knowledge.
} 
Table 1: Tense and agreement morphology in Danish, Icelandic and Övdalian.

\begin{tabular}{|c|c|c|c|c|c|c|}
\hline \multirow[t]{2}{*}{ Infl. } & \multicolumn{2}{|c|}{ Danish } & \multicolumn{2}{|c|}{ Icelandic } & \multicolumn{2}{|c|}{ Övdalian } \\
\hline & $\begin{array}{c}\text { present } \\
\text { tense }\end{array}$ & $\begin{array}{l}\text { past } \\
\text { tense }\end{array}$ & $\begin{array}{c}\text { present } \\
\text { tense }\end{array}$ & $\begin{array}{l}\text { past } \\
\text { tense }\end{array}$ & $\begin{array}{c}\text { present } \\
\text { tense }\end{array}$ & $\begin{array}{l}\text { past } \\
\text { tense }\end{array}$ \\
\hline $1 \mathrm{sg}$. & hør-er & hør-te & heyr-i & heyr-ð-i & är-er & är-d-e \\
\hline $2 \mathrm{sg}$. & hør-er & hør-te & heyr-ir & heyr-ð-ir & är-er & är-d-e \\
\hline $3 \mathrm{sg}$. & hør-er & hør-te & heyr-ir & heyr-ð-i & är-er & är-d-e \\
\hline $1 \mathrm{pl}$. & hør-er & hør-te & heyr-um & heyr-ð-um & är-um & är-d-um \\
\hline $2 \mathrm{pl}$. & hør-er & hør-te & heyr-ið & heyr-ð-uð & är-ið / är-ir ${ }^{8}$ & är-d-ið / är-d-ir \\
\hline $3 \mathrm{pl}$. & hør-er & hør-te & heyr-a & heyr-ð-u & är-a & är-d-e \\
\hline
\end{tabular}

Given the morphological data presented in Table 1, we expect Icelandic and Övdalian to exhibit Split-IP. Here, the morphological evidence is sufficient, as we observe "multiple inflectional morphemes on the verb stem, specifically the co-occurrence of discrete tense and agreement morphemes" (cf. Bobaljik \& Thráinsson 1998:67). ${ }^{9}$ Accordingly, if the value of the SIP is positive, the predictions for a language are the following (Bobaljik \& Thráinsson 1998:67):

- the availability of two subject positions (being a prerequisite to the higher subject position in expletive constructions and to Transitive Expletive Constructions),

- the availability of two object positions (being a prerequisite to the Object Shift of full DP-objects) and

- the requirement that the verb raises out of the VP in non-V2-environments.

\footnotetext{
${ }^{8}$ The second person plural verbal ending $-i ð /-i r$ reflects the dialectal variation of Övdalian.

${ }^{9}$ The authors argue (see above) that there are other cues in the input for the positive value of the IP-parameter, verb raising and transitive expletives. In this way, syntactic evidence can also suffice to set the split-IP parameter.
} 
The final point is the strongest prediction: once the SIP is set positive in a language, the language will always show V-to-I movement. The other two predictions are less strong: these phenomena are possibly but not obligatorily found in languages with a positive SIP setting. For the phenomena object shift and expletives, the split IP is a "necessary, but not sufficient condition" (Bobaljik and Thráinsson 1998:61).

The mentioned constructions are all illustrated below for Icelandic. The higher subject position in expletive constructions (HiPos) is illustrated in (1), the Transitive Expletive Construction (TEC) in (2), the Object Shift of a full DP-object in (3), and the verb raising out of the VP in a non-V2-environment in (4).

(1) Pað hefur einhver köttur verið $i$ eldhúsinu. (Icelandic) IT HAS SOME CAT BEEN IN KITCHEN.DEF

"There has been a cat in the kitchen".

(from Bobaljik \& Thráinsson 1998:55)

(2) Pað hefur einhver köttur étið mýsnar. (Icelandic) IT HAS SOME CAT EATEN MICE.DEF

"A cat has eaten mice".

(from Bobaljik \& Thráinsson 1998:56)

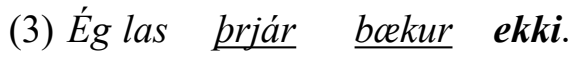
(Icelandic)
I READ THREE BOOKS NOT
"I didn't read three books".

(from Bobaljik \& Thráinsson 1998:53) 

(4) Раð er nú pað sem ég veit ekki.
(Icelandic)
THAT IS NOW IT THAT I KNOW NOT
“That's exactly what I don't know".

(from Bobaljik \& Thráinsson 1998:64)

Since the occurrence of separate tense and agreement morphemes is said to be the crucial evidence for determining the value of the SIP, I will in the following investigate whether the correlation between such marking and the four syntactic constructions is maintained in the dialects of Ovansiljan. I will begin with a presentation of the inflectional paradigm of each, and then I will examine whether the TEC, the higher subject position in expletive constructions, Object Shift of full DP-objects and Vfin-Adv word order in all types of embedded clauses $\left(\mathrm{V}^{0}\right.$-to- $\mathrm{I}^{0}$ movement $)$ are accepted in the vernaculars ${ }^{10}$.

Of course, Bobaljik and Thráinsson (1998:61) open the possibility of syntactic evidence being the clue for determining the positive value of the SIP. When conclusions are drawn on the evidence of SIP in each vernacular, both types of evidence are therefore taken into account.

\subsection{Inflectional evidence of Split-IP in the Ovansiljan vernaculars}

In the vernaculars spoken in Älvdalen, Mora, Sollerön and Våmhus, tense and agreement endings are clearly separable in the $1^{\text {st }}$ and $2^{\text {nd }}$ person plural, both in the present and in past tense (cf. Tables 2-5 below), whereas in the vernacular of Orsa, the endings are only

\footnotetext{
${ }^{10}$ In these sections, the syntactic analysis of each construction will not receive much attention. The present paper aims to test the generalizations about the clustering of phenomena, and the relation between morphology and syntax in the Ovansiljan vernaculars. The detailed account of the syntax underlying the relevant phenomena is not at stake, and my points about the empirical evidence (or lack thereof) in Ovansiljan are independent of these analyses. The detailed accounts and analyses can be found in Bobaljik \& Thráinsson (1998).
} 
separable in the $1^{\text {st }}$ and $2^{\text {nd }}$ person plural when the verb follows the subject (Table 6). ${ }^{11}$ The vernaculars of Venjan and Ore represent the Mainland Scandinavian verbal inflection type without separate morphemes for tense and agreement, as shown in Table 7 and Table 8.

Table 2: Inflectional morphology in Övdalian, the verb spilå - "play”.

\begin{tabular}{|c|c|c|c|c|}
\hline \multirow[t]{3}{*}{ Infl. } & \multirow{2}{*}{\multicolumn{2}{|c|}{$\begin{array}{c}\text { PRESENT } \\
\text { TENSE }\end{array}$}} & \multirow{2}{*}{\multicolumn{2}{|c|}{$\begin{array}{c}\text { PAST } \\
\text { TENSE }\end{array}$}} \\
\hline & & & & \\
\hline & SINGULAR & PLURAL & SINGULAR & PLURAL \\
\hline 1 & spil-är & spil-um & 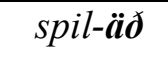 & spil-äð-um \\
\hline 2 & spil-är & spil-ir / spil-id & spil-äð & 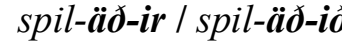 \\
\hline 3 & spil-är & spil-å & spil-äð & spil-äð \\
\hline
\end{tabular}

Table 3: Inflectional morphology in the vernacular of Mora (Färnäs), the verb spilå - "play”.

\begin{tabular}{|c|c|c|c|c|}
\hline \multirow[t]{2}{*}{ Infl. } & \multicolumn{2}{|c|}{$\begin{array}{c}\text { PRESENT } \\
\text { TENSE }\end{array}$} & \multicolumn{2}{|c|}{$\begin{array}{l}\text { PAST } \\
\text { TENSE }\end{array}$} \\
\hline & SINGULAR & PLURAL & SINGULAR & PLURAL \\
\hline 1 & spil-är & spil-um & 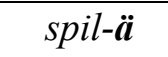 & 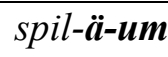 \\
\hline 2 & spil-är & spil-ir & 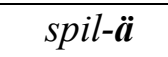 & 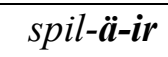 \\
\hline 3 & 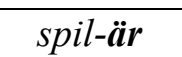 & spil-å & spil- $\ddot{\boldsymbol{a}}$ & spil-ä \\
\hline
\end{tabular}

Table 4: Inflectional morphology in the vernacular of Sollerön, the verb läka - "play".

\begin{tabular}{|l|c|c|}
\hline Infl. & PRESENT & PAST \\
& TENSE & TENSE \\
\hline
\end{tabular}

${ }^{11}$ This rule is, however, absent in the variant of the vernacular spoken in the village of Skattungbyn, where the person endings are always in the present tense (Eva Olander p.c.). 


\begin{tabular}{|c|c|c|c|c|}
\hline & SINGULAR & PLURAL & SINGULAR & PLURAL \\
\hline 1 & läk-är & läk-um & $l a ̈ k-\ddot{a} t$ & läk-ät-um \\
\hline 2 & $l a ̈ k-\ddot{a r} r$ & läk-ir & $l a ̈ k-\ddot{a} t$ & läk-ät-ir \\
\hline 3 & läk-är & $l a ̈ k-(a)$ & $l a ̈ k-\ddot{a} t$ & $l a ̈ k-\ddot{a} t$ \\
\hline
\end{tabular}

Table 5: Inflectional morphology in the vernacular of Våmhus, the verb båkå - "bake".

\begin{tabular}{|c|c|c|c|c|}
\hline \multirow[t]{2}{*}{ Infl. } & \multicolumn{2}{|c|}{$\begin{array}{c}\text { PRESENT } \\
\text { TENSE }\end{array}$} & \multicolumn{2}{|c|}{$\begin{array}{l}\text { PAST } \\
\text { TENSE }\end{array}$} \\
\hline & SINGULAR & PLURAL & SINGULAR & PLURAL \\
\hline 1 & $b \ddot{a} k-\ddot{a}$ & bak-um & bäk-äd & bäk-äd-um \\
\hline 2 & $b \ddot{a} k-\ddot{a}$ & bak-ið & $b \ddot{a} k-\ddot{a} d$ & bäk-äd-ið \\
\hline 3 & $b \ddot{a} k-\ddot{\boldsymbol{a}}$ & båk-å & $b \ddot{a} k-\ddot{a} d$ & $b \ddot{a} k-\ddot{a} d$ \\
\hline
\end{tabular}

Table 6: Inflectional morphology in the vernacular of Orsa (the village of Orsa), the verb spilå - "play".

\begin{tabular}{|c|c|c|c|c|}
\hline \multirow{3}{*}{ Infl. } & \multirow{2}{*}{\multicolumn{2}{|c|}{$\begin{array}{c}\text { PRESENT } \\
\text { TENSE }\end{array}$}} & \multirow{2}{*}{\multicolumn{2}{|c|}{$\begin{array}{l}\text { PAST } \\
\text { TENSE }\end{array}$}} \\
\hline & & & & \\
\hline & SINGULAR & PLURAL $^{12}$ & SINGULAR & PLURAL $^{13}$ \\
\hline 1 & spil-är & spil-öm / spil & spil-äd & 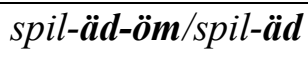 \\
\hline 2 & spil-är & spil-i/spil & spil-äd & 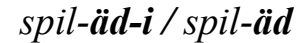 \\
\hline 3 & spil-är & spil-å & spil-äd & spil-äd \\
\hline
\end{tabular}

\footnotetext{
${ }^{12}$ The $1^{\text {st }} \mathrm{pl}$. ending $-\ddot{o} m$ and the $2^{\text {nd }} \mathrm{pl}$. ending $-i$ are only present when the subject is preverbal.

${ }^{13}$ The $1^{\text {st }} \mathrm{pl}$. ending $-\ddot{o} m$ and the $2^{\text {nd }} \mathrm{pl}$. ending $-i$ are only present when the subject is preverbal.
} 
Table 7: Inflectional morphology in the vernacular of Ore, the verb attra - "change".

\begin{tabular}{|c|c|c|c|c|}
\hline \multirow[t]{2}{*}{ Infl. } & \multicolumn{2}{|c|}{$\begin{array}{c}\text { PRESENT } \\
\text { TENSE }\end{array}$} & \multicolumn{2}{|c|}{$\begin{array}{l}\text { PAST } \\
\text { TENSE }\end{array}$} \\
\hline & SINGULAR & PLURAL & SINGULAR & PLURAL \\
\hline 1 & åtr-är & åtr-om 14 / åtr-är & åtr-ed & åtr-ed-om 15 / åtr-ed \\
\hline 2 & åtr-är & $\stackrel{a}{a t r}-\ddot{a} r$ & åtr-ed & åtr-ed \\
\hline 3 & åtr-är & àtr-är & åtr-ed & åtr-ed \\
\hline
\end{tabular}

Table 8: Inflectional morphology in the vernacular of Venjan, the verb kassta - "throw".

\begin{tabular}{|c|c|c|c|c|}
\hline \multirow[t]{2}{*}{ Infl. } & \multicolumn{2}{|c|}{$\begin{array}{c}\text { PRESENT } \\
\text { TENSE }\end{array}$} & \multicolumn{2}{|c|}{$\begin{array}{c}\text { PAST } \\
\text { TENSE }\end{array}$} \\
\hline & SINGULAR & PLURAL & SINGULAR & PLURAL \\
\hline 1 & kasst-är & 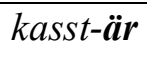 & kasst-ed/kasst-ät & kasst-ed / kasst-ät \\
\hline 2 & kasst-är & kasst-är & kasst-ed/kasst-ät & kasst-ed / kasst-ät \\
\hline 3 & kasst-är & 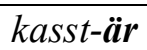 & kasst-ed / kasst-ät & kasst-ed / kasst-ät \\
\hline
\end{tabular}

Given the data presented in tables 2 through 8, I conclude that Övdalian, as well as the vernaculars of Mora, Orsa, Sollerön and Våmhus, have clearly separable endings for agreement and tense (although only with preverbal subjects in the vernacular of Orsa), which should be enough evidence to trigger Split-IP in these under the approach of Bobaljik and Thráinsson (1998). The vernaculars of Ore and Venjan do not display separable endings for tense and agreement, and I assume that the morphological evidence is not enough to set a

\footnotetext{
14 The form åtrom is considered archaic (Ann-Christine Elings Blomberg, p.c.).

15 The form åtredom is considered archaic (Ann-Christine Elings Blomberg, p.c.).
} 
positive value for the SIP. ${ }^{16}$ According to Bobaljik and Thráinsson (1998:61), the positive value of the SIP can, however, be triggered by the embedded V-Adv word order or by transitive expletive constructions in these vernaculars.

\subsection{Syntactic evidence of Split-IP in the Ovansiljan vernaculars}

The syntactic evidence for split-IP will be discussed in the next subsections. There are two reasons to doing this. Firstly, there is a need to check whether vernaculars with morphological evidence of SIP show syntactic consequences, and secondly it is important to see whether vernaculars without morphological evidence still show syntactic evidence to set SIP.

4.2.1 $V^{0}$-to-I $I^{0}$ movement. In V2-languages like the Ovansiljan vernaculars, movement of $\mathrm{V}^{0}$ to $\mathrm{I}^{0}$ can only be observed in embedded clauses, in which the verb is expected to precede adverbs. This is illustrated for Icelandic in (4) above. As shown in Garbacz (2010:119 ff.), the order $\mathrm{V}-\mathrm{Adv}$ in all types of embedded clauses (i.e. the effect of $\mathrm{V}^{0}$-to- $\mathrm{I}^{0}$ movement) is still possible but no longer obligatory in Övdalian; see (5). Similar data from Övdalian have also been presented by Angantýsson (2011:91).

(5) Eð ir iend buotje so ig (ar) aldri (ar) lesið. (Övdalian) IT IS ONLY BOOK.DEF THAT I HAVE NEVER HAVE READ

"This is the only book that I have never read".

Instead of obligatorily moving the finite verb before the adverb, two patterns are preferred in Övdalian embedded clauses: the Mainland Scandinavian embedded word order (Adv-V) and

\footnotetext{
${ }^{16}$ The loss of agreement in number and person in Ore must have occurred quite recently, as Levander (1928:170 ff.) notes that the vernacular of Ore exhibits separate endings for the $1^{\text {st }}$ and $2^{\text {nd }}$ person plural.
} 
the embedded word order with the adverbial preceding the subject (Garbacz 2010:123 ff.); compare with (6). ${ }^{17}$

(6) Eð ir iend buotje so (aldri) ig (aldri) ar lesið. (Övdalian) IT IS ONLY BOOK.DEF THAT (NEVER) I (NEVER) HAVE READ

"This is the only book that I have never read".

To the best of my knowledge, V-Adv in all types of embedded clauses is also possible in the vernacular of Mora - at least it is accepted by some of the consulted speakers; as in the examples in (7) - and in the vernacular of Orsa, where some of the consultants prefer it to verb-in-situ; see (8).

a) $\ddot{A} d \quad$ va sind att (int) ann (int) besötjä (int) våss $i$ går. (Mora)

IT WAS PITY THAT NOT HE NOT VISITED NOT US YESTERDAY

"It was a pity that he didn't visit us yesterday".

b) $\ddot{A} d \quad e \quad n a ̊ \quad s a ̊ \quad$ (åldär) $\mathrm{i}$ (åldär) $\underline{a} \quad$ (åldär) djort. (Mora) IT IS SOMETHING THAT NEVER I NEVER HAVE NEVER DONE "It is something that I have never done".

(8) a) $\ddot{A}$ wa armliatt (int) ånn (?int) älst $\quad$ (int) o wöss igår. (Orsa) IT WAS PITY THAT NOT HE NOT GREETED NOT ON US YESTERDAY "It was a pity that he didn't visit us yesterday".

\footnotetext{
${ }^{17}$ Note here that the postadverbial subject is still located in Spec-TP, not, for example in Spec-vP; I refer to Garbacz (2010:100-103) for a discussion on that matter. I adopt this analysis for all the vernaculars of Ovansiljan exhibiting postadverbial subjects.
} 
b) Belgien $i$ jätt lånd dar (int) i (int) $\underline{a}(-$ nt) weri aldri. (Orsa)

BELGIUM IS A COUNTRY WHERE NOT I NOT HAVE-NOT BEEN NEVER

"Belgium is a country which I have never visited".

Like Övdalian, the vernaculars of Mora and Orsa allow the Mainland Scandinavian embedded word order and the placement of sentential adverbs before the subject. The vernaculars of Våmhus, Ore and Venjan do not exhibit the embedded V-Adv in all types of embedded clauses at all, displaying instead the (Adv)-Subject-(Adv)-Vfin embedded word order. This is also the case of the vernacular of Sollerön spoken by younger speakers (born in the 1950s). Older speakers (born in the 1930s) do accept structures with $\mathrm{V}^{0}$-to- $\mathrm{I}^{0}$ effects.

4.2.2 Transitive expletive constructions. Bobaljik and Thráinsson (1998:55) argue that a splitIP, which has several subject positions, is a prerequisite for transitive expletive constructions (TECs). TECs can for example be found in Icelandic, as illustrated in (2) above. TECs are present in the vernaculars of Mora, Orsa, Sollerön and Venjan, as exemplified in (9) through (12).

Äd a nån stuli män bil.

(Mora)

IT HAS SOMEBODY STOLEN MY CAR

"Somebody has stolen my car".

\begin{tabular}{|c|c|c|c|c|}
\hline$\ddot{A} a$ & nön & stuli & bil'n & männ \\
\hline IT HAS & SOMEBODY & STOLEN & CAR.DEF & MINE \\
\hline
\end{tabular}




$\begin{array}{rlllllll}\text { (11)a) } \ddot{A} \text { a } & \text { jänn rev } & \text { täj } & \text { önor } & \text { fö } & \text { våss. } & \text { (Sollerön) } \\ \text { IT HAS } & \text { A } & \text { FOX } & \text { TAKEN } & \text { FOWLS } & \text { FOR } & \text { US }\end{array}$

"A fox has taken our fowls".

b) $\ddot{A}$ a nånn iti upp kaku.

(Sollerön)

IT HAS SOMEBODY EATEN UP CAKE.DEF

"Somebody has eaten the cake".

c) $\ddot{A}$ a mångg studentär lesi botji. $\quad$ (Sollerön)

IT HAS MANY STUDENTS READ BOOK.DEF

"Many students have read the book".
(12)a) $\ddot{A}$ a nån stule biln männ.
IT HAS SOMEBody STOLEN CAR.DEF MINE
"Somebody has stolen my car".
b) $\ddot{A}$ a jänn röv täj hönnsä worå.
IT HAS A FOX TAKEN FOWLS.DEF OURS
"A fox has taken our fowls".

Interestingly, TECs are absent in Övdalian (Garbacz 2010:71), see (13), as well as in the vernaculars of Våmhus and Ore, see (14) and (15), respectively. Nota bene that the sentences equivalent to those in (13)-(15) in which the NP-subject is initial, have been judged as fully grammatical by the consultants. The possibility of having non-initial, non-referential subjects has, however, not been examined. 
*Eठ ar ien övkall tjyöpt stugu.

(Övdalian)

IT HAS A ÖVDALIAN BOUGHT HOUSE.DEF

“An Övdalian has bought the house".

(14)a) * $*$ a någä åjtlänningär tsiöpa Matsas aus. (Våmhus) IT HAS SOME FOREIGNERS BOUGHT MATS' HOUSE

"Some foreigners have bought the Mats' house".

b) $* \ddot{A}$ a nån stuli männ bil.

(Våmhus)

IT HAS SOMEBODY STOLEN MY CAR

"Somebody has stolen my car".

$\begin{array}{lllll}(15) \mathrm{a}) * \ddot{A} \text { a môngär studenter läst botje. } & \text { (Ore) }\end{array}$

IT HAS MANY STUDENTS READ BOOK.DEF

"Many students have read the book".

b) $* \ddot{A}$ a nôn jäte upp kako.

(Ore)

IT HAS SOMEBODY EATEN UP CAKE.DEF

"Somebody has eaten the cake".

c) * $\ddot{A}$ a nôn räv täje hönsner fô wôss.

(Ore)

IT HAS ONE FOX TAKEN FOWLS.DEF FOR US

"A fox has taken our fowls". 
4.2.3 Higher subject position in expletive constructions (HiPos). Bobaljik and Thráinsson (1998:67) claim that the availability of two subject positions is a prerequisite to the higher subject position in expletive constructions (HiPos). Example (1) above illustrates HiPos in Icelandic. The construction is found in the vernaculars of Mora, Orsa, Sollerön and Venjan; see (16)-(19).

(16)a) $\ddot{A} d \quad$ a jätt par dansa å gardim.

(Mora)

IT HAS A COUPLE DANCED ON GARDEN.DEF

“A couple has danced in the garden".

b) $\ddot{A} d \quad$ a je katta väri i(nni) tjötji.

(Mora)

IT HAS A CAT BEEN IN KITCHEN.DEF

"A cat has been in the kitchen."

(17)a) $\ddot{A} a$ jätt par dånsad $i$ gardem.

(Orsa)

IT HAS A COUPLE DANCED IN GARDEN.DEF

"A couple has danced in the garden".

b) $\ddot{A}$ a je katta weri ini tjetji.

(Orsa)

IT HAS A CAT BEEN IN KITCHEN.DEF

"A cat has been in the kitchen".

(18)a) $\ddot{A}$ a jätt par dannsa $i$ gardim.

(Sollerön)

IT HAS A COUPLE DANCED IN GARDEN.DEF

“A couple has danced in the garden". 
b) $\ddot{A}$ a je $\boldsymbol{k a t t}^{\prime}$ ve $i$ tjötji.

(Sollerön)

IT HAS A CAT BEEN IN KITCHEN.DEF

"A cat has been in the kitchen".

(19) a) $\ddot{A} a \quad$ nå gadfolk käme frå Ståkkålm.

(Venjan)

IT HAS SOME GUESTS COME FROM STOCKHOLM

"Some guests have come from Stockholm".

b) $\ddot{A} a \quad$ jänn $\quad$ kattkall wäj åjti tjötjä.

IT HAS A CAT-MAN BEEN OUT-IN KITCHEN.DEF

"A tomcat has been in the kitchen".

HiPos is, however, not found in the vernacular of Våmhus, see (20); the vernacular of Ore, see (21) or of Övdalian, see (22).
(20)a) * $\ddot{A}$ a je katta we auti tsjötsi.
(Våmhus)
IT HAS A CAT BEEN OUT-IN KITCHEN.DEF
"A cat has been in the kitchen".
b) * $\ddot{A} \quad$ a främmand kämi frå Stockola.
IT HAS STRANGERS COME FROM STOCKHOLM
(Våmhus)
"Some guests have come from Stockholm".
(21)a) * $\ddot{A}$ a nôgär djästär käme frå Stôckhôlm. $\quad$ (Ore)
IT HAS SOME GUESTS COME FROM STOCKHOLM
"Some guests have come from Stockholm".


b) $* \ddot{A} \quad a \quad$ jäna katta wäre $t i \quad$ tjötjä.

IT HAS A CAT.FEM BEEN OUT-IN KITCHEN.DEF

"A she-cat has been in the kitchen".

(22) a)*Eठ ar iett par dansað $i$ garðem. (Övdalian)

IT HAS A COUPLE DANCED IN GARDEN.DEF

"A couple has danced in the garden".

b) *Eð ar nog dşäster kumið frạ Stokkol. (Övdalian)

IT HAS SOME GUESTS COME FROM STOCKHOLM

"Some guests have come from Stockholm".

c) *Eठ ar ien katt werið $i$ tşyötşę.

(Övdalian)

IT HAS A CAT BEEN IN KITCHEN.DEF

"A cat has been in the kitchen."

4.2.4 Full DP object shift. Finally, Bobaljik \& Thráinsson (1998:67) claim that the possibility of two object positions (only possible in languages with a split-IP) is a prerequisite for full DP object shift. Object shift is found in Icelandic, as illustrated in (3) above. However, object shift of DP-objects does not exist in any of the seven Ovansiljan vernaculars and nor does the object shift of pronominal objects; compare with (23)-(29).
(23) a)*I läst botje int. / I läst'nt botje.
(Ore)
I READ BOOK.DEF NOT / I READ-NOT BOOK.DEF.
"I didn't read the book". 

b) *I läst na int. / I läst'nt na.
(Ore)
I READ HER NOT / I READ-NOT HER
"I didn't read it".
(24) a)*Ig tsiöpäd buotsi int. / Ig tsiöpäd int buotsi. (Våmhus)
I BOUGHT BOOK.DEF NOT / I BOUGHT NOT BOOK.DEF.

"I didn't buy the book".
b) *I las na int. / I las'nt na. (Våmhus)
I READ HER NOT / I READ-NOT HER
"I didn't read it".
(25)a) *I les nå tidningär ent. / I les'ent nå tidningär. (Venjan)
I READ ANY NEWSPAPERS.DEF NOT / I READ-NOT ANY NEWSPAPERS.DEF
"I don't read any newspapers".
b) *Dåm snodd änn-ent åjt. / Dåm snodd-ent åjt änn. (Venjan)
THEY THREW HIM-NOT OUT / THEY THREW-NOT OUT HIM
“They didn't throw him out”.

\author{
(26)a) *I les tiningär innt. / I les innt tiningär. (Sollerön) \\ I READ NEWSPAPERS.DEF NOT / I READ NOT NEWSPAPERS.DEF \\ "I don't read the newspapers".
}


b) *Dämm snodd ann innt åjjt. / Dämm snodd innt åjjt ann. (Sollerön)

THEY THREW HIM NOT OUT / THEY THREW NOT OUT HIM

“They didn't throw him out".

(27)a) *I les tidninggär int. / I les int tidninggär. (Orsa)

I READ NEWSPAPERS.DEF NOT / I READ NOT NEWSPAPERS.DEF

"I don't read the newspapers".

b) *Däm windöd ån int ajt. / Däm windöd int ajt ån. (Orsa)

THEY THREW HIM NOT OUT / THEY THREW NOT OUT HIM

"They didn't throw him out".

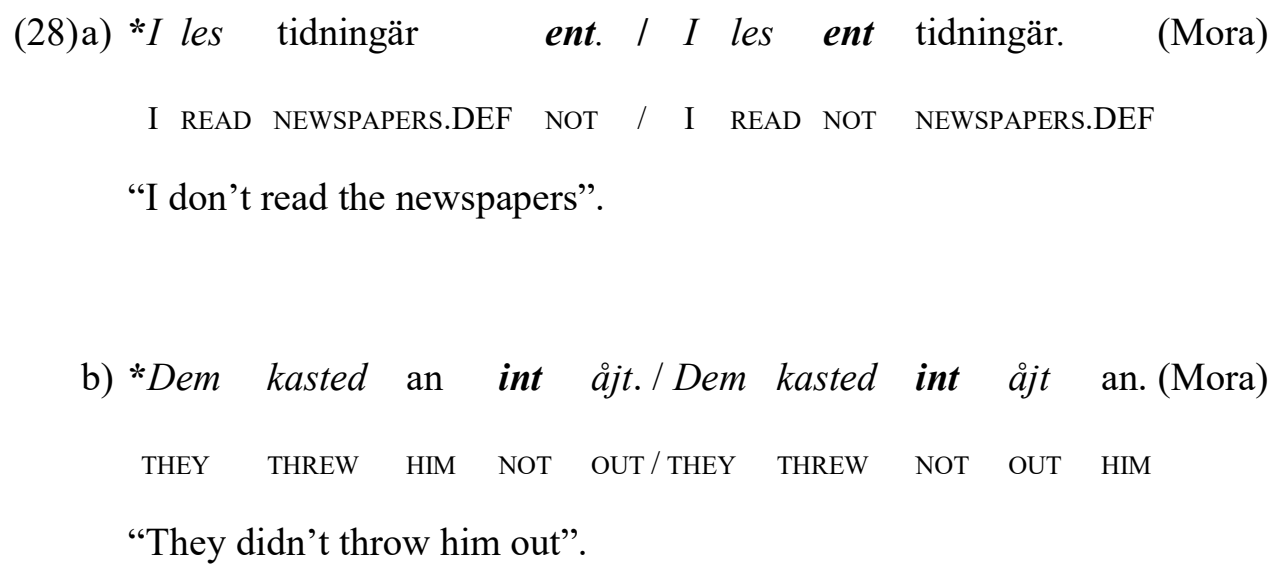

b) *Dem kasted an int åjt./Dem kasted int åjt an. (Mora) THEY THREW HIM NOT OUT / THEY THREW NOT OUT HIM

“They didn't throw him out".

(29)a) * Ig tjyöpt buotję inte/it. / Ig tjyöpt int/it buotję. (Övdalian)

I BOUGHT BOOK.DEF NOT / I BOUGHT NOT BOOK.DEF.

"I didn't buy the book". 

b) *An såg mig inte/it. / An såg int/it mig.
(Övdalian)
HE SAW ME NOT / HE SAW NOT ME

“He didn’t see me".

\subsection{Syntactic and morphological evidence for Split-IP in Ovansiljan - conclusions}

The empirical results concerning both inflectional morphology and syntax in the vernaculars of Ovansiljan and the theoretical predictions of Bobaljik and Thráinsson (1998) are summarized in Table 9 below.

Table 9: Syntax of the Ovansiljan vernaculars.

\begin{tabular}{|c|c|c|c|c|c|c|c|}
\hline & Övdalian & $\begin{array}{c}\text { The } \\
\text { vernacular } \\
\text { of Våmhus }\end{array}$ & $\begin{array}{c}\text { The } \\
\text { vernacular } \\
\text { of Mora }\end{array}$ & $\begin{array}{c}\text { The } \\
\text { vernacular } \\
\text { of Sollerön }\end{array}$ & $\begin{array}{c}\text { The } \\
\text { vernacular } \\
\text { of Orsa }\end{array}$ & $\begin{array}{c}\text { The } \\
\text { vernacular } \\
\text { of Venjan }\end{array}$ & $\begin{array}{c}\text { The } \\
\text { vernacular } \\
\text { of Ore }\end{array}$ \\
\hline $\begin{array}{l}\text { SEPARATE } \\
\text { ENDINGS } \\
\text { FOR TENSE } \\
\text { AND } \\
\text { AGREEMENT }\end{array}$ & + & + & + & + & + & - & - \\
\hline$V^{0}-T O-I^{0}$ & non- & no & $\begin{array}{c}\text { non- } \\
\text { obligatory }\end{array}$ & $\begin{array}{c}\text { no / } \\
\text { possible, } \\
\text { but non- } \\
\text { obligatory } \\
\text { for older } \\
\text { speakers }\end{array}$ & non- & no & no \\
\hline $\begin{array}{l}\text { FULL DP } \\
\text { OBJECT }\end{array}$ & no & no & no & no & no & no & no \\
\hline
\end{tabular}




\begin{tabular}{|c|c|c|c|c|c|c|c|}
\hline SHIFT & & & & & & & \\
\hline TEC & no & no & yes & yes & yes & yes & no \\
\hline HIPOs & no & no & yes & yes & yes & yes & no \\
\hline EVIDENCE & + & + & + & + & + & + & \\
FOR SIP & $\begin{array}{c}\text { (morph \& } \\
\text { syntax })\end{array}$ & $($ morph $)$ & $\begin{array}{c}\text { (morph \& } \\
\text { syntax })\end{array}$ & $\begin{array}{c}\text { syntax }) \\
\text { syntax })\end{array}$ & (syntax $)$ & \\
\hline
\end{tabular}

As the table shows, six of the discussed vernaculars exhibit evidence for a positive setting of the SIP. Only in the vernacular of Ore, no evidence for SIP is found. In the vernacular of Venjan, there is only syntactic evidence, and in the vernacular of Våmhus there is only morphological evidence for SIP. The other vernaculars show both morphological and syntactic evidence for SIP.

Given the data presented above, there are some problematic facts regarding Bobaljik and Thráinsson's (1998) approach, including

(i) that the five properties that according to them cluster together cross-linguistically, do not cluster together in most of the Ovansiljan vernaculars (only in Ore, where all five phenomena are absent);

(ii) a lack of obligatory embedded Vfin-Adv order (the effect of $\mathrm{V}^{0}$-to- $\mathrm{I}^{0}$ movement) in the vernaculars of Övdalian, Mora, Sollerön and Orsa, and the complete lack of it in the vernacular of Våmhus, despite the morphological (and in some cases also syntactic) evidence for SIP; and

(iii) the lack of V-to-I movement in Venjan, despite the syntactic evidence for SIP in this dialect in the form of presence of TEC and HiPos. 
The first point is the least problematic one. Although Bobaljik \& Thráinsson (1998) argue that all phenomena cluster together in the Germanic languages they investigate, they already suggest that this unification might be incorrect (Bobaljik \& Thráinsson 1998:67). The Ovansiljan data under discussion here clearly show that it is a simplification to unify all phenomena: they only cluster together in one of the seven vernaculars (viz., the vernacular of Ore). The lack of full DP object shift in all the vernaculars and the lack of TEC and HiPos in Övdalian do not necessarily contradict the theory: Bobaljik \& Thráinsson (1998) predict that these phenomena are only possible in languages with a split IP, but not that these phenomena have to occur. These patterns are thus not directly problematic for the theory, but they certainly seem to disprove the clustering of all phenomena.

Let us now have a closer look at the other two problems mentioned above, which are more serious. As for the lack of the obligatory embedded Vfin-Adv word order, Thráinsson (2010:1084) claims in a later paper that Övdalian may exhibit obligatory $\mathrm{V}^{0}$-to- $\mathrm{I}^{0}$ movement, as - given its verbal morphology - it should, under his approach, but that this may be blurred by a higher (post-subject) adverb position, located between AgrSP and TP (such solution has been proposed for the Icelandic embedded V3 word order, see e.g. Angantýsson 2011:106 ff.): ${ }^{18}$

To conclude, it is clear that the verb placement facts in Älvdalsmålet are much more complex and messy than previously believed, and it is not at all clear yet what is required to account for them in a satisfactory manner. But if the evidence for separate tense and agreement markers is still clear, then $\mathrm{B}$ [obaljik] \& $\mathrm{T}$ [hráinsson] maintain that

\footnotetext{
18 Angantýsson (ibid.) contrasts two embedded clauses with an indefinite subject, out of which the first is grammatical and the other not: (i) Dað var Hrafnkels saga sem einhver hafði ekki lesið (lit. IT WAS HRAFNKELS SAGA THAT SOMEBODY HAS NOT READ) and (ii) * Dað var Hrafnkels saga sem einhver ekki hafði lesið (lit. IT WAS HRAFNKELS SAGA THAT SOMEBODY NOT HAS READ). Note that the same structure as that in (ii) is grammatical, when the subject is a personal pronoun, such as hann ("he") or a DP, such as Haraldur.
} 
Älvdalsmålet should have split IP and more "subject positions" than standard MSc and hence allow transitive expletives. If that is true, then instances of [the] Adv-Vfin order in embedded clauses in Älvdalsmålet have to be attributed to [the] "exceptional" placement of sentence adverbs, which is then possibly becoming less exceptional than it is in Icelandic because of [the] influence from Standard Swedish. [footnote omitted]

This line of argument would apply to all the vernaculars discussed above which clearly have separate endings for tense and agreement. But if so, one would expect to observe a contrast between definite/specific subjects (located in AgrSP) and indefinite subjects (located in TP) with respect to co-occurrence with the word order Vfin-Adv, cf. Angantýsson (2011:107). However, there is no evidence for such a contrast in Övdalian, nor in the vernaculars of Mora and Orsa. The post-adverbial subjects in all the vernaculars are assumed to be located in Spec,TP, not in Spec,vP. As recently shown by Viðarsson (2016), the solution to explaining the embedded V3 in Icelandic proposed by Angantýsson (2011:106 ff.) fails when applied to $19^{\text {th }}$-century Icelandic.

Koeneman \& Zeijlstra (2014:581-582) also argue that Övdalian exhibits V-to-I movement, even in the instances in (5) and (6). According to their analysis, Övdalian has three positions for the negation: above the subject, above IP and above V. Only when the negation is in the lowest position, V-to-I movement can be observed. In their analysis, the high placement of the negation is thus obscuring the movement of $\mathrm{V}$ to $\mathrm{I}$. The same logic would apply to the other vernaculars with separate endings for tense and agreement. However, one needs then an independent evidence for such a low position for the negation. I agree with Koeneman \& Zeijlstra (2014:582) that the occurrence of Vfin-Adv orders in Övdalian indicates that V-to-I movement is possible in this vernacular. I disagree however with the conclusion that this movement is obligatory: there does not seem to be independent evidence 
for this claim. The same applies to the vernaculars of Mora, Orsa and Sollerön (for older speakers), where V-to-I movement is possible but not obligatory, in contrast with the predictions of Bobaljik \& Thráinsson (1998). Furthermore, Koeneman \& Zeijlstra's (2014) logic does not apply to the vernacular of Våmhus, that never shows V-to-I movement, unless we assume a syntactic position (i.e. a low negation) for which we have no other evidence than the theory we are testing.

The third problem for the theory of Bobaljik \& Thráinsson relates to the vernacular of Venjan. The presence of TEC and HiPos in this vernacular does not have to be problematic. Remember that under the approach of Bobaljik and Thráinsson (1998), syntactic evidence can also be the trigger of Split-IP. However, if the Split-IP parameter is set based on syntactic evidence, one would still expect V-to-I movement to be obligatory. This is not the case, as Vto-I movement is not found at all in the vernacular of Venjan. As for the other vernaculars, there is no independent evidence to assume a low negation along the lines of Koeneman \& Zeijlstra (2014).

Most of the vernaculars (Mora, Orsa, Sollerön, Venjan and Övdalian) seem to exhibit Split-IP and some of the effects of it, while the vernacular of Ore does not. The data show us both that the SIP can be acquired despite the lack of clear syntactic evidence (as in Övdalian) as well as the contrary situation: that a positive value of the SIP can be set despite the lack of morphological evidence (as in the vernacular of Venjan). However, in both situations it is problematic for the theory that there is no, or no obligatory, V-to-I movement.

The vernacular of Venjan behaves in one respect as some variants of spoken Swedish from the 1920 s - that is, in exhibiting both TEC and HiPos, despite no morphological evidence for 
a positive setting of the SIP-parameter; see the examples of TEC and HiPos in Swedish in (30a) and (30b), respectively. ${ }^{19}$

$\begin{array}{rlllll}\text { (30)a) Det får väl någon } & \text { annan } & \text { överta } & \text { vakten } & \text { då (...). } \\ \text { IT MUST THEN SOMEBODY } & \text { ELSE } & \text { TAKE-OVER } & \text { WATCH.DEF } & \text { THEN }\end{array}$

"In this case, somebody else must take over the watch".

(from Ljunggren 1926:352)

\begin{tabular}{|c|c|c|c|c|}
\hline b) (...) och det & kunde & hela & eftermiddagen & $g a ̊(\ldots)$. \\
\hline AND IT & COULD & WHOLE & AFTERNOON.DEF & $\mathrm{GÅ}$ \\
\hline
\end{tabular}

(from Ljunggren 1926:351)

The Swedish influence, a factor that Thráinsson (2010:1084) mentions in the quote above, is an important factor, but to my mind it should not be overestimated. Övdalian can serve as example here: It exhibits syntactic structures (e.g. referential null subjects, multiple subjects and negative concord) that are robust in the language, although they are absent in Swedish (Garbacz \& Johannessen 2015:42). This argumentation applies to the other Ovansiljan vernaculars as well, so any claim that they are developing "into" Swedish would hence be a

\footnotetext{
19 TEC is also attested in (some variants of) contemporary spoken Swedish, as shown in Nordberg (2005), and especially in Håkansson (2017). Nordberg's (2005) material consists of transcribed recordings of people born before 1965, but the construction is found most frequently among those born before 1935 (Nordberg 2005:146). The subject in the construction, however, is - according to Nordberg (2005:149) - never indefinite. Given that there were no HiPos in the Swedish reported by Nordberg (2005), only TEC, the language would be another example of a language showing some effects of the Split-IP in absence of any morphological and other syntactic clues for a positive setting of the parameter. Håkansson (2017) writes that the occurrence of TEC in Swedish "suggests that the constructin is completely independent of licencing factors as verbal agreement and verb movement" (2017:256) and claims instead that "TEC are licensed if the expletive pronoun can merge in a position structurally higher than the canonical subject position" (ibid.).
} 
simplification. An investigation of the degree to which standard Swedish influences them lies, however, outside the scope of the present article. ${ }^{20}$

The data from the vernaculars of Ovansiljan presented above are highly relevant for the hypothesis of Bobaljik and Thráinsson (1998), who state themselves (1998:67) that their proposal "attempts to unify, perhaps incorrectly, all five [phenomena]". It seems that their theory embraces much of the data, also those data from the until-now syntactically unexplored vernaculars of Ovansiljan, but it also fails on some points. First, as Thráinsson (2010:1084) notes himself, the Adv-Vfin embedded word order in the vernaculars with clearly separate endings for tense and agreement (such as Övdalian) is problematic. This also applies to the vernaculars of Våmhus, Mora, Sollerön and Orsa. This word order cannot be explained by a low placement of the subject in Spec,vP or by a low placement of negation, as stated above. One could ask here: Is the IP both split and unsplit, resulting in an embedded Vfin-Adv/AdvVfin word order, or is the expected $\mathrm{V}^{0}$-to- $\mathrm{I}^{0}$ movement just absent? Second, despite the syntactic evidence for Split-IP (the presence of TEC and HiPoS) in Venjan, V-to-I movement is not found in this vernacular.

\section{Holmberg (2010a): $\varphi$-features in T}

Holmberg's (2010a) study is another, and more recent, attempt to explain one morphological and six syntactic differences within the branch of Scandinavian languages by tracing them back to abstract $\varphi$-features in T. Whereas Insular Scandinavian (which in Holmberg's 2010a paper is represented solely by Icelandic) exhibits (1) rich subject-verb agreement, (2) oblique subjects, (3) Stylistic Fronting, (4) null expletives, (5) null generic subject pronoun, (6)

\footnotetext{
${ }^{20}$ In Garbacz (2010:138 ff.), it is claimed that Swedish has played a catalysing (yet not the most important) role in the ongoing loss of the $\mathrm{V}^{0}$-to- $\mathrm{I}^{0}$ movement in Övdalian, but that the pre-subject placement of negation in Övdalian has blurred the evidence for verb movement to $I^{0}$. The same argumentation could be used for the other Ovansiljan vernaculars, as they all exhibit such pre-subject placement of negation.
} 
transitive expletives (TEC) and (7) heavy subject postposing, Mainland Scandinavian (represented in the paper by standard varieties of Swedish, Danish and Norwegian) does not exhibit any of these phenomena.

The seven differences between I[nsular] Sc[andinavian] and M[ainland] Sc[andinavian] I started out with, a reduced version of P[latzack]\&H[olmberg]'s list, have been explained as effects of variation with regard to $\varphi$-features in T: ISc has [uPn] and [uNr]; MSc has neither. This is morphologically reflected in the agreement on the finite verb. It causes [the] incorporation, in the sense of Roberts (2010a, 2010) of a defective, D-less pronoun. A direct result of this is the null generic pronoun and the null expletive. An indirect result is the pure expletive, merged directly with TP, which, in turn, makes the TEC and Heavy Subject Postposing possible. Another indirect result is the possibility of oblique subjects and SF.

(Holmberg 2010:35 ff.)

The prediction is that the above-mentioned properties should cluster in the Scandinavian languages and in their non-standard varieties. Null expletive subjects ${ }^{21}$ and null generic subjects $^{22}$ are expected in the varieties that have an unvalued person feature ([uPn]) and an unvalued number feature $([\mathrm{uNr}])$ in $\mathrm{T}$ (such as in Icelandic). Oblique subjects, Stylistic Fronting, transitive expletives (TEC) and heavy subject postposing are unexpected in varieties with a valued person feature and a valued number feature in $\mathrm{T}$ (such as in Swedish). Since the null generic pronoun and the null expletive are argued to be a direct result of [uPn] and

\footnotetext{
${ }^{21}$ Holmberg (2010a:27): "After Agree, the subject will, again, be a copy of T, hence a non-head member of a chain headed by T, will therefore not be attracted by the EPP, and will not be spelled-out".

${ }^{22}$ Holmberg (2010a:26): "The absence of a null generic pronoun in Norwegian and the other MSc languages is a direct consequence of the absence of $u \phi$-features in $T$ which would make possible establishing a chain ( $T$, subject pronoun)".
} 
$[\mathrm{uNr}]^{23}$, we expect that varieties that exhibit rich agreement will also obligatorily display null expletive subjects and null generic subjects.

The notion of "rich" agreement is - although crucial for the hypothesis - not defined by Holmberg (2010a). This lack of definition has been criticized by Dahl and KoptjevskajaTamm (2010), and Holmberg (2010b) answers to the critique as follows:

As for pinning down exactly how rich agreement should be to license, in this case, [the] incorporation of a deficient (D-less) pronoun, I remain sceptical. In Holmberg \& Platzack (1995) we gave up this ambition after observing a variety of attempts to pin down how rich agreement needed to be to trigger verb movement (Roberts (1994), Rohrbacher (1999), Vikner (1997), among others), based on generalisations over observed languages and dialects, but which seemed to always be falsified by the next language or dialect investigated. Either the relation between agreement inflection morphology and syntactic properties is less direct than we would like it to be, or we are not operating with the right $\varphi$-feature theory (but see Müller, 2005 and Roberts, 2010a for a different opinion).

Holmberg (2010b:88)

Although the central notion needed for a typological prediction is not defined by Holmberg (2010a), the hypothesis will nevertheless be tested below ${ }^{24}$, and it will be assumed that the Icelandic and Old Swedish type of agreement can be considered rich. In this way, I will treat the agreement in Övdalian and in the vernaculars of Våmhus, Mora, Sollerön and Orsa, as examples of rich agreement, whereas I will treat the agreement in the vernaculars of Ore and

\footnotetext{
${ }^{23}$ See the previous two footnotes for the argumentation of Holmberg (2010a). As for the previous section, the exact analysis of the syntax underlying the relevant phenomena is not at stake here. Rather, the claims about clustering of the relevant morphological and syntactic phenomena is tested in the group of Ovansiljan vernaculars (cf. footnote 11 above).

${ }^{24}$ This lack of definition of what "rich" agreement is shows very clearly the importance of testable predictions in empirical science.
} 
Venjan as "poor". ${ }^{25}$ The relevant paradigms are given in Section 4.1 above, and the syntactic expectations for the seven vernaculars of Ovansiljan are presented in Table 10 below.

Table 10: Typological expectations given Holmberg (2010a).

\begin{tabular}{|c|c|c|c|c|c|c|c|}
\hline & Övdalian & $\begin{array}{c}\text { The } \\
\text { vernacular } \\
\text { of Våmhus }\end{array}$ & $\begin{array}{c}\text { The } \\
\text { vernacular } \\
\text { of Mora }\end{array}$ & $\begin{array}{c}\text { The } \\
\text { vernacular } \\
\text { of Sollerön }\end{array}$ & $\begin{array}{c}\text { The } \\
\text { vernacular } \\
\text { of Orsa }\end{array}$ & $\begin{array}{c}\text { The } \\
\text { vernacular } \\
\text { of Venjan }\end{array}$ & $\begin{array}{c}\text { The } \\
\text { vernacular } \\
\text { of Ore }\end{array}$ \\
\hline AGR & rich & rich & rich & rich & rich & poor & poor \\
\hline $\begin{array}{l}\text { OBLIQUE } \\
\text { SUBJECTS }\end{array}$ & possible & possible & possible & possible & possible & impossible & impossible \\
\hline $\begin{array}{l}\text { STYLISTIC } \\
\text { FrONTING }\end{array}$ & possible & possible & possible & possible & possible & impossible & impossible \\
\hline $\begin{array}{l}\text { NULL } \\
\text { EXPLETIVES }\end{array}$ & obligatory & obligatory & obligatory & obligatory & obligatory & impossible & impossible \\
\hline $\begin{array}{l}\text { NULL } \\
\text { GENERIC } \\
\text { SUBJECT } \\
\text { PRONOUN }\end{array}$ & obligatory & obligatory & obligatory & obligatory & obligatory & impossible & impossible \\
\hline $\begin{array}{l}\text { TRANSITIVE } \\
\text { EXPLETIVES } \\
\text { (TEC) }\end{array}$ & possible & possible & possible & possible & possible & impossible & impossible \\
\hline $\begin{array}{l}\text { HEAVY } \\
\text { SUBJECT } \\
\text { POSTPOSING }\end{array}$ & possible & possible & possible & possible & possible & impossible & Impossible \\
\hline
\end{tabular}

\footnotetext{
${ }^{25}$ Koeneman and Zeijlstra (2014: 574) formulate a definition of rich agreement. Under their definition, a language exhibits rich agreement if "agreement involves at least the same featural distinctions as those manifested in the smallest (subject) pronoun inventories universally possible". The relevant feature distinctions are $[ \pm$ speaker], $[ \pm$ participant $]$ and $[ \pm$ plural]. Following Koeneman and Zeijlstra (2014), the classification of the Ovansiljan vernaculars is the same as assumed in this paper.
} 
Below, I show the syntactic constructions that are either predicted to be impossible, possible or obligatory, given that the given language/vernacular exhibits rich agreement, which is an indication of having an unvalued person feature $([\mathrm{uPn}])$ and an unvalued number feature $([\mathrm{uNr}])$ in $\mathrm{T}$. This is in order to check whether data from any of the discussed vernaculars may contradict the hypothesis presented in Holmberg (2010).

\subsection{Stylistic Fronting}

According to Holmberg (2010), Stylistic Fronting (SF) should only be possible in languages with rich agreement. None of the Ovansiljan vernaculars allows SF; see (31). Note that corresponding sentences without SF are judged to be perfectly grammatical by all the consultants. Traces of what looks like SF are found in (at least) the vernacular of Orsa; see

$$
\begin{aligned}
& \text { (31)a) *An jält iett tal fer diem so slutað add skaulan. (Övdalian) } \\
& \text { HE HELD A SPEECH FOR THOSE THAT FINISHED HAD SCHOOL.DEF } \\
& \text { "He gave a speech for those who had finished the school". }
\end{aligned}
$$

b) $* O$ waist mig ollt so gart ward inistugun. (Våmhus) SHE SHOWED ME EVERYTHING THAT DONE BECAME IN HOUSE.DEF "He showed me everything that was done in the house".

c) *Ann jäld jätt tal fö däm så sluta add skauln. (Mora) HE HELD A SPEECHFOR THOSE THAT FINISHED HAD SCHOOL.DEF "He gave a speech for those who had finished the school". 
d) *Ann höll jätt tal fô dämm summ sluta haddä ti skolan. (Ore) HE HELD A SPEECH FOR THOSE THAT FINISHED HAD TO SCHOOL.DEF "He gave a speech for those who had finished the school".

e) *Ann alld jätt tal fär däm sö sluta add skoln. (Orsa) HE HELD A SPEECH FOR THOSE THAT FINISHED HAD SCHOOL.DEF "He gave a speech for those who had finished the school".

f) *An älld jätt tal fö dämm så sluta add skåjlan. (Sollerön) HE HELD A SPEECH FOR THOSE THAT FINISHED HAD SCHOOL.DEF "He gave a speech for those who had finished the school".

g) *An hälld jätt tal a dåm så sluta add skoln. (Venjan) HE HAD A SPEECH FOR THOSE THAT FINISHED HAD SCHOOL.DEF "He gave a speech for those who had finished the school".

\section{(32)a) ?Wi skumm fråg onöm so gamblöst/ ynggst $i$. WE Shall ASK HIM that OLDEST / YOUNGST IS} "We shall ask him who is the oldest".

b) ?Wi sö ajti värdn åmm bott... (Orsa) WE THAT OUT-IN WORLD.DEF HAVE LIVED "We, who have lived abroad...."

Despite the sentences presented in (32), it does not seem plausible to assume that the vernacular of Orsa displays SF. What the examples could possibly tell us is that SF could 
have disappeared from the vernacular of Orsa later than from the other vernaculars or that the consulted speakers were particularly conservative. In addition, examples similar to (32) are possible in standard Swedish, and these are often considered to be frozen expressions.

\subsection{Oblique subjects}

Oblique subjects are in Holmberg's (2010a) approach argued to be possible only in languages with rich agreement. None of the vernaculars allows oblique subjects; see (33). In the examples below, the lack of oblique subjects is shown by the verb dröma/dräma "to dream" taking a nominative subject, but the lack of oblique subjects has been examined in many other contexts, too.
(33)a) I går
(Övdalian)
YESTERDAY DREAMED I/ME A STRANGE DREAM
"Yesterday, I dreamed a strange dream".
b) Igår drömd ig/*mig jenn kunstugan dröm.
(Våmhus)

YESTERDAY DREAMED I/ME A STRANGE DREAM
"Yesterday, I dreamed a strange dream".
c) I nåt drömä o/*änn jän grann dröm.
TONIGHT DREAMED SHE/HER A BEAUTIFUL DREAM
(Mora)
"Yesterday, she dreamed a beautiful dream".
d) I nåt drömdä o/*onär jänn grann dräm.
TONIGHT DREAMED SHE/HER A BEAUTIFUL DREAM
"Last night, she dreamed a beautiful dream".


e) I nåt drömät o/*ännä jänn däl dröm.

(Sollerön)

TONIGHT DREAMED SHE/HER A NICE DREAM

"Last night, she dreamed a nice dream".

f) Nåtä så wa drömed ̊̊/*̈̈nn sågale fint.

(Venjan)

NIGHT THAT WAS DREAMED SHE/HER SÅ VERY BEAUTIFUL

"Last night, she had a beautiful dream".

g) I nåt drämd o/*ännär jänn finan dräm

(Ore)

TONIGHT DREAMED SHE/HER A BEAUTIFUL DREAM

"Tonight, she dreamed a beautiful dream".

\subsection{Heavy subject postposing}

Following Holmberg (2010a), the postposing of heavy subjects is predicted to be possible only in languages with rich agreement. Heavy subject postposing is not an option in any of the discussed vernaculars; see the examples in (34). Corresponding sentences, in which the subject directly follows the finite verb and precedes the object, are judged as perfectly grammatical by all the consultants.

(34)a) *Fôrårä tjöft issa hôjsä jänn ungan karr frå Stôckhôlm. (Ore)
LAST-YEAR BOUGHT THIS HOUSE.DEF A YOUNG MAN FROM STOCKHOLM
"Last year, a young man from Stockholm bought this house".


b) *Ifiuord tjyöpt å-dar stugu ien unggan kall frå Falu. (Övdalian) LAST-YEAR BOUGHT THIS HOUSE.DEF A YOUNG MAN FROM FALUN "Last year, a young man from Falun bought this house".

c) *Förra årä tsiöpäd itta ausa jenn ung påikfrå Falu. (Våmhus) LAST YEAR BOUGHT THIS HOUSE.DEF A YOUNG MAN FROM FALUN "Last year, a young man from Falun bought this house".

d) *Ifiörd tjöpt itta öjse jän ungg kall frå Stokkol. (Mora) LAST-YEAR BOUGHT THIS HOUSE.DEF A YOUNG MAN FROM STOCKHOLM "Last year, a young man from Stockholm bought this house".

e) *Ifjörd tjept deda ajse jänn ungg kall frå Stokkol. (Orsa) LAST-YEAR BOUGHT THIS HOUSE.DEF A YOUNG MAN FROM STOCKHOLM "Last year, a young man from Stockholm bought this house".

f) *Ifjord tjöpät ita åjsä jänn ungg kall frå Övdalim.(Sollerön) LAST-YeAR BOUght THIS HOUSE.DEF A YOUNG MAN FROM ÄLVDALEN "Last year, a young man from Älvdalen bought this house".

g) *Förår tjöped don stugu jänn ingär karr frå Mora. (Venjan) LAST-YEAR BOUGHT THIS HOUSE.DEF A YOUNGER MAN FROM MORA "Last year, a young man from Mora bought this house". 


\subsection{Expletive subjects and generic subjects}

Based on Holmberg (2010a), null expletive subjects and null generic subjects are predicted to be obligatory in languages with rich agreement, but impossible in languages with poor agreement. None of the vernaculars allows the omission of expletives and of generic subjects; see the examples in (35)-(39).
(35) a)
Nu raingner *(eð) mitjið.
(Övdalian)
NOW RAINS
IT A-LOT
"It rains a lot these days".
b) Jär får *(an) it rötja.
HERE GETS ONE NOT SMOKE

"Smoking is not allowed here".

(36)
a) Jär raingnä *(äð) mitsi.
(Våmhus)
HERE RAINS
IT A-LOT
"It rains a lot here".

b) Jär får int *(an) rätsa.

HERE GETS NOT ONE SMOKE

"Smoking is not allowed here".
a) $N u$ raingnä *(äd) mytji.
(Mora)
NOW RAINS
IT A-LOT
"It rains a lot these days". 

b) Dan fånt *(an) rötja.
THERE GETS-NOT ONE SMOKE
"Smoking is not allowed here".

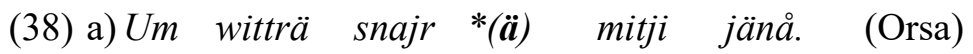 ON WINTERS SNOWS IT A-LOT HERE
"It snows a lot here in the winter".
b) Dånä fo'nt *(ånn) rätja.
THERE GETS-NOT ONE SMOKE

"Smoking is not allowed here".
(39)
a) $N u \quad$ rängnär $*(\ddot{a}) \quad$ mytji.
NOW RAINS IT A-LOT
"It rains a lot these days".
b) Dan få *(an) innt rätja. THERE GETS ONE NOT SMOKE "Smoking is not allowed here".

\subsection{Transitive expletives}

Given Holmberg (2010a), transitive expletive constructions (TECs) are expected to be possible in languages with rich agreement but impossible in languages with poor agreement. As was shown in section 4.2.2 above, TECs are possible in the vernaculars of Mora, Orsa, Sollerö and Venjan, but not in Övdalian and not in the vernaculars of Våmhus and Ore either. 


\section{$5.6 \varphi$-features in $T$-conclusion}

A summary of the findings presented above is given in Table 11. The cases where the empirical data deviate from the theoretical expectations (cf. Table 10) have been shadowed.

Table 11: Syntax of the Ovansiljan vernaculars.

\begin{tabular}{|c|c|c|c|c|c|c|c|}
\hline & Övdalian & $\begin{array}{c}\text { The } \\
\text { vernacular } \\
\text { of Våmhus }\end{array}$ & $\begin{array}{c}\text { The } \\
\text { vernacular } \\
\text { of Mora }\end{array}$ & $\begin{array}{c}\text { The } \\
\text { vernacular } \\
\text { of Sollerön }\end{array}$ & $\begin{array}{c}\text { The } \\
\text { vernacular } \\
\text { of Orsa }\end{array}$ & $\begin{array}{l}\text { The } \\
\text { vernacular } \\
\text { of Venjan }\end{array}$ & $\begin{array}{c}\text { The } \\
\text { vernacular } \\
\text { of Ore }\end{array}$ \\
\hline AGR & rich & rich & rich & rich & rich & poor & poor \\
\hline $\begin{array}{l}\text { OBLIQUE } \\
\text { SUBJECTS }\end{array}$ & no & no & no & no & no & no & no \\
\hline $\begin{array}{l}\text { StYLISTIC } \\
\text { Fronting }\end{array}$ & no & no & no & no & no & no & no \\
\hline $\begin{array}{l}\text { NULL } \\
\text { EXPLETIVES }\end{array}$ & no & no & no & no & no & no & no \\
\hline $\begin{array}{l}\text { NULL } \\
\text { GENERIC } \\
\text { SUBJECT } \\
\text { PRONOUN }\end{array}$ & no & no & no & no & no & no & no \\
\hline $\begin{array}{l}\text { TRANSITIVE } \\
\text { EXPLETIVES } \\
\text { (TEC) }\end{array}$ & no & no & yes & yes & yes & yes & no \\
\hline $\begin{array}{l}\text { HEAVY } \\
\text { SUBJECT } \\
\text { POSTPOSING }\end{array}$ & no & no & no & no & no & no & no \\
\hline
\end{tabular}

There is a number of findings that are unexpected, given Holmberg's (2010a) hypothesis.

First, the predicted obligatory incorporation of expletives and generic subjects in the 
vernaculars with rich agreement (Övdalian, Våmhus, Mora, Sollerön and Orsa) is not found at all. Second, the vernacular of Venjan exhibits transitive expletives but behaves in all other respects as the Mainland Scandinavian languages. As it has only "poor" agreement, it is unclear what enables TEC in the vernacular of Venjan, given the approach of Holmberg (2010a). ${ }^{26}$ Out of the seven vernaculars, only the vernacular of Ore behaves as predicted by Holmberg (2010a). In order to retain the approach of Holmberg (2010a), despite the data presented above, one needs to propose an additional factor (or several factors) that could explain the lack of null expletives and null generic subjects in Övdalian as well as in the vernaculars of Våmhus, Mora, Sollerön and Orsa. Yet another additional factor (or several factors) should be determined to explain the presence of TEC in the vernacular of Venjan. Holmberg (2010b:89) notes himself that his proposal faces a problem when confronted with Övdalian data: "The particular mix exhibited by Oevdalian is not completely consistent with $\mathrm{P} \& \mathrm{H}$, including the version in my paper". Here, I have shown that not only Övdalian, but also the rest of the vernaculars of Ovansiljan, with the exception of the vernacular spoken in Ore, are inconsistent with the proposal of Holmberg (2010a).

It can be added that Övdalian has lost SF during the $20^{\text {th }}$ century - a loss that was not accompanied (or triggered) by any changes in the verbal inflection (pointed out by Garbacz 2010:164 and by Dahl \& Koptievskaja-Tamm 2010:50 ff.), and that the vernacular of Orsa has lost the possibility of omitting expletive subjects (this possibility is reported in Björk 1910:43), whereas this loss has not been accompanied by a change from "rich" to "poor" verbal agreement. These facts are yet another challenge to the approach of Holmberg (2010a) that relates the "richness" of verbal agreement morphology to the clustering of syntactic phenomena. It must be however pointed out that the predictions made by Holmberg (2010a)

\footnotetext{
${ }^{26}$ And also in the Swedish data reported by Ljunggren (1926) and Nordberg (2005).
} 
do fit better with the data than those made by Bobaljik \& Thráinsson (1998), without being able to capture these completely.

\section{Summary and conclusions}

In the present paper, I have discussed the hypotheses of Bobaljik and Thráinsson (1998) and of Holmberg (2010a), both expressing a connection between morphology and syntax within a parametric framework. Although these make correct predictions for the standard forms of the majority of the Nordic languages, they seem to get into some trouble when confronted with the empirical evidence from the Swedish vernaculars of Ovansiljan.

The main question is whether it is possible to account for the new data within the scope of the two approaches discussed above. Bobaljik and Thráinsson (1998) maintain that the morphological or syntactic evidence is a trigger for the positive value of the Split-IP parameter, which in turn is responsible for the obligatory $\mathrm{V}^{0}$-to- $\mathrm{I}^{0}$ movement and which also enables TEC, HiPos and full-DP Object Shift. However, the fact that these vernaculars do not or only optionally exhibit V-to-I movement is problematic even for this unidirectional hypothesis. Especially for those vernaculars that display other syntactic evidence or for SIP. Holmberg (2010b:88), as already mentioned above, states the following: "Either the relation between agreement inflection morphology and syntactic properties is less direct than we would like it to be, or we are not operating with the right $\varphi$-feature theory (but see Müller, 2005 and Roberts, 2010a for a different opinion)". If the relation between agreement inflection morphology and syntactic properties is indirect, one would like to know how one could prove that there is a relation indeed.

The two hypotheses presented by Bobaljik and Thráinsson (1998) and Holmberg (2010a) are a part of a long tradition of connecting morphology with syntax. In the present paper, I have shown that neither the approach of Bobaljik and Thráinsson (1998) nor that of Holmberg 
(2010a) completely succeeded in accounting for the evidence from the Ovansiljan vernaculars. These results can be seen as an objection raised against a relation between 'rich' verbal inflection on the one hand and several syntactic phenomena on the other hand. Although Bobaljik \& Thráinsson (1998) and Holmberg (2010a) use different criteria for rich morphology (i.e. what is enough morphological evidence to influence the syntax), both approaches can be tested in the Ovansiljan vernaculars. However, both approaches run into problems when confronted with the data presented in this paper.

The results presented above can be seen as yet another objection raised against the parametric approach to Scandinavian syntax, but that is not the discussion at stake here. The main objective is not to test whether the parametric approach can account for the data, but rather whether the data can be captured by a relation between syntax and morphology. The data presented here clearly lead to a negative answer to that question, at least for a direct relation between syntax and morphology.

On the other hand, it should be emphasised that the search for parametric correlations between syntax and morphology has been very successful, not because it has proved these correlations but because it has increased our knowledge of the Scandinavian language branch enormously, both diachronically and geographically. This body of research has thus not only contributed theoretically, but also empirically to the field of Scandinavian linguistics. The present paper specifically aimed for this by including the until now less studied Ovansiljan vernaculars.

\section{References}

Andersson M. \& S. Danielsson. 1999. Färdär frå Soldn = Spår från Sollerön : en ordbok på soldmål. Sollerön. 
Angantýsson, Á. 2011. The syntax of embedded clauses in icelandic and related languages. Reykjavík: Hugvísindastofun Háskóla Íslands.

Ask, B. 2000. Våmhus: ordlista: svenska-våmhusmål jämte kortfattad grammatik samt våmhusmål-svenska: ett urval grundformer. Våmhus: Bonäs-Våmhus pensionärsförening.

Björk, A. 1910. Orsamål: anteckningar. Svenska landsmål och svenskt folkliv 113. 43-56.

Björklund, S. 1994. Några diftongvarianter i sollerömål och grannmål i Ovansiljan. Dalmålsstudier. Festskrift till Stig Björklund på 75-årsdagen den 19 februari 1994, 179-181. Uppsala: Dialekt- och folkminnesarkivet.

Bobaljik, J. D. \& Thráinsson. 1998. Two heads aren't always better than one. Syntax 1(1). $37-$ 71.

Boeckx, C. 2010. What principles and parameters got wrong. Ms. http://ling.auf.net/lingBuzz/001118 Accessed 1 $1^{\text {st }}$ December 2015.

Boeckx, C. 2012. Considerations pertaining to the nature of logodiversity, or How to construct a parametric space without parameters. Ms. http://ling.auf.net/lingBuzz/001453 Accessed $1^{\text {st }}$ December 2015.

Boëthius, J. 1907. Oremålets ställning inom dalmålet. Svenska landsmål och svenskt folkliv 110. $65-73$.

Boëthius, J. 1918. Orsamålet 1: Ljudlära. Stockholm: Norstedt.

Borer, H. 1984. Parametric syntax. Dordrecht: Foris.

Chomsky, N. 1981. Lectures on government and binding. Dordrecht: Foris.

Dahl. Ö. 1998. Vad är dalmål? Institutionen för lingvistik, Stockholm universitet, Stockholm.

Dahl, Ö. 2005. Att sätta älvdalskan på kartan. 1st Conference on Övdalian, Älvdalen, 18-19 June 2004. http://uu.diva-portal.org/smash/get/diva2:431173/FULLTEXT03.pdf Accessed $1^{\text {st }}$ December 2015. 
Dahl, Ö \& M. Koptjevskaja-Tamm. 2010. Rich agreement, everything else being equal and large-scale cross linguistic comparison. Theoretical Linguistics 36. 49-56.

Garbacz, P. 2010. Word order in Övdalian. A study in variation and change. Doktorsavh. Lund: Språk- och litteraturcentrum, Lunds universitet.

Garbacz, P. \& J. Bondi Johannessen. 2015. Övdalian from 1909 to 2009. In K. Bentzen, H. Rosenkvist \& J. Bondi Johannessen (eds.), Studies in Övdalian morphology and syntax: New research on a lesser-known Scandinavian language. Linguistik Aktuell/Linguistics Today 221. 11-46.

Håkansson, D. 2008. Syntaktisk variation och forandring. En studie av subjektslosa satser $i$ fornsvenska. Doctoral dissertation, Språk- och litteraturcentrum, Lunds universitet.

Håkansson, D. 2017. Transitive expletive constructions in Swedish. Nordic Journal of Linguistics 40 (3), 255-285.

Hallberg, G. 2005. Dialects and regional linguistics varieties in the 20th century in Sweden and Finland. In O. Bandle, K. Braunmüller, E-H Jahr, A. Karker, H-P Naumann, U. Teleman, L. Elmevik \& G. Widmark (eds.), 1691-1706. The Nordic languages: an international handbook of the history of the North Germanic languages. Berlin/New York: Walter de Gruyter.

Holmberg, A. 2010a. Parameters in minimalist theory: The case of Scandinavian. Theoretical Linguistics 36. 1-48.

Holmberg, A. 2010b. Replies to comments. Theoretical Linguistics 36. 8591.

Holmberg, A. \& C. Platzack. 1995. The role of inflection in Scandinavian syntax. New York/Oxford: Oxford University Press.

Hrafnbjargarson, G.H. \& A.-L. Wiklund. 2010: AGR and V2. Theoretical Linguistics 36. 5768. 
Koeneman, O. \& H. Zeijlstra. 2014. The rich agreement hypothesis rehabilitated. Linguistic Inquiry 45. 571-615.

Larsson, G., B. Welin \& U. Welin. 2008. Hur många talar älvdalska idag? Second Conference on Elfdalian, Älvdalen, 12-14 June 2008.

Levander, L. 1909. Älvdalsmålet i Dalarna. Ordböjning ock syntax. Stockholm: Kungliga boktryckeriet P. A. Norstedt ock söner.

Levander, L. 1925. Dalmålet. Beskrivning och historia. I. Uppsala.

Levander, L. 1928. Dalmålet. Beskrivning och historia. II. Uppsala.

Lightfoot, D. W. 1979. Principles of diachronic syntax. Cambridge: Cambridge University Press.

Ljunggren, R. 1926. Om den opersonliga konstruktionen. Uppsala: Berlings.

Måsan, S. 2002. Det finns ju bara ett sollerömål i hela Sverige. I: Ater till Sollerön: om kulturarv, folk och landsbygd. Larsson, Cecilia Hammarlund, Bo Larsson, Annette Rosengren (red.). Stockholm: Nordiska museets förlag: 105-116.

Müller, G. 2005. Pro-drop and impoverishment. In P. Brandt \& E. Fuss (eds.), 93-115. Form, structure, and grammar. A Festschrift presented to Günter Grewendorf on the occasion of his $60^{\text {th }}$ birthday. Tübingen: Narr.

Newmeyer, F. 2004. Against a parameter-setting approach to language variation. Linguistic Variation Yearbook 4. 181-234.

Newmeyer, F. 2006. A rejoinder to 'On the role of parameters in Universal Grammar: a reply to Newmeyer' by Ian Roberts and Anders Holmberg. http://people.pwf.cam.ac.uk/mtb23/NSP/Rejoinder\%20to\%20R\&H.pdf Accessed $1^{\text {st }}$ December 2015. 
Newmeyer, F. 2008. Holmberg and Platzack: The typological dimension. Talk at Revisiting Parameters: Holmberg and Platzack (1995) Reloaded. Lund University, $16^{\text {th }}-17^{\text {th }}$ October 2008.

Nordberg, B. 2005. Expletivt det i samtalsspråk. In Bäcklund, I. et al. Text $i$ arbete/Text at work. Festskrift till Britt-Louise Gunnarsson den 12 januari 2005. Uppsala: Institutionen för nordiska språk: 144-152.

Noreen, A. 1881. Dalmålet I. Inledning till Dalmålet. Svenska landsmål ock svenskt folklif IV. 1. 2-23.

Ohlsén K. \& E. Olander. 2010. Orsaord: en orsamålsordbok. Mora: Orsa-Skattunge hembygdsförening.

Roberts, I. 1994. Verbs and diachronic syntax: A comparative history of English and French. Dordrecht: Kluwer.

Roberts, I. 2010a. A deletion analysis of null subjects. In: T. Biberauer, A. Holmberg, I. Roberts \& M. Sheehan (eds.), 58-87. Parametric variation: Null subjects in minimalist theory. Cambridge: Cambridge University Press.

Roberts, I. 2010. Agreement and head movement: Clitics, incorporation and defective goals. Cambridge, MA: MIT Press.

Rohrbacher, B. W. 1999. Morphology-driven syntax, a theory of V to I raising and pro-drop. Amsterdam, Philadelphia: John Benjamins.

Sandøy, H. 1994. Talesyntaks og dialektsyntaks. Myking, Sandøy og Utne (eds.) Helsing til Lars Vassenden på 70-årsdagen. Bergen: Nordisk institutt, Universitetet i Bergen.

Steensland, L. 2000. Älvdalska. In K. Vamling \& J-O Svantesson (eds.), 361-375. Världens språk - en typologisk och geografisk översikt. Institutionen för lingvistik, Lunds universitet, Lund.

Tannerhagen, T. 1913. Oremålet. Olsmässan: tidning för Ore gammelby med omnejd: 9. 
Thráinsson, H. 1996. On the non-universality of functional categories. In W. Abraham, S. D. Epstein, H. Thráinsson \& C. J-W Zwart (eds.), 253-281. Minimal Ideas. Syntactic Studies in the Minimalist Framework. Amsterdam: John Benjamins.

Thráinsson, H. 2007. The syntax of Icelandic. New York: Cambridge University Press.

Thráinsson, H. 2010. Predictable and unpredictable sources of variable verb and adverb placement in Scandinavian. Lingua 120. 1062-1088.

Viðarsson, Heimir van der Feest. 2016. The syntax of others: "un-Icelandic" verb placement in nineteenth- and early twentieth-century Icelandic. In van Ostade \& Percy (eds.), 152167. Prescription and Tradition in Language: Establishing Standards Across Time and Space. Bristol: Multilingual Matters.

Vikner, S, 1997. V-to-I movement and inflection for person in all tenses. In L. Haegeman (ed.), 187-213. The New Comparative Syntax. London: Longman.

Wennberg, K. 2007. Wenjad: en ordbok. Orsa: Orsa tryckeri. 